\title{
Natural Remediation of Arsenic Contaminated Ground Water Associated With Landfill Leachate
}

Concentrations of arsenic that exceed the drinking water standard of $10 \mu \mathrm{g} / \mathrm{L}$ (micrograms per liter) (U.S. Environmental Protection Agency, 2001) are a common problem in New England water-supply wells (Zuena and Keane, 1985; Marvinney and others, 1994; Ayotte and others, 1999; Peters and others, 1999). Much of the arsenic occurs naturally in certain rock types of the region and enters ground water through weathering (Ayotte and others, 2003).

Anthropogenically induced changes in ground-water chemistry also can cause release of arsenic from the solid phase to ground water. Precipitation and ground water seeping through municipal waste in landfills produce leachate that is contaminated with various organic and inorganic substances from the landfill waste (Baedecker and Back, 1979; Christensen and others, 2001). Leachate seeping from a landfill contaminates the ground water beneath the landfill. The ground-water contamination also extends away from the landfill in the direction of ground-water flow, forming a leachate plume that can result in the release of naturally occurring arsenic.

This fact sheet describes results of studies by the U.S. Geological Survey at the Saco Municipal Landfill, Saco, Maine. The source of arsenic in ground water and effects of landfill leachate on arsenic concentration in ground water are described.

\section{SACO LANDFILL}

The Saco Municipal Landfill (fig. 1) was operated from the early 1960s to 1989 and consists of three separate landfill areas (Nielsen and others, 1995). Landfill Areas 1 and 2 are located on the east side of Sandy Brook and have been capped since 1976 and 1989. Natural arsenic concentrations in the bedrock and sediments beneath Areas 1 and 2 are relatively low [3.0 - $6.9 \mathrm{mg} / \mathrm{kg}$ (milligrams per kilogram)] (Stollenwerk and Colman, 2003) and the average arsenic concentration in leachate-contaminated ground water is $21 \mu \mathrm{g} / \mathrm{L}$ (range $<3.0-50$ $\mu \mathrm{g} / \mathrm{L}$ ) (Woodard and Curran, 1998). Arsenic concentrations in uncontaminated ground water upgradient from the landfill areas range from $<3.0-28 \mu \mathrm{g} / \mathrm{L}$ (Woodard and Curran, 1998).

Landfill Area 4 is on the west side of Sandy Brook. This landfill has been inactive since 1989 and was covered with an impermeable membrane in 1998. The geology of Area 4 is distinctly different from Areas 1 and 2, and the bedrock and sediments contain greater concentrations of naturally occurring arsenic $(6.8-51.0 \mathrm{mg} / \mathrm{kg})$. Leachate from the Area 4 landfill has contaminated surficial alluvium and the upper part of the

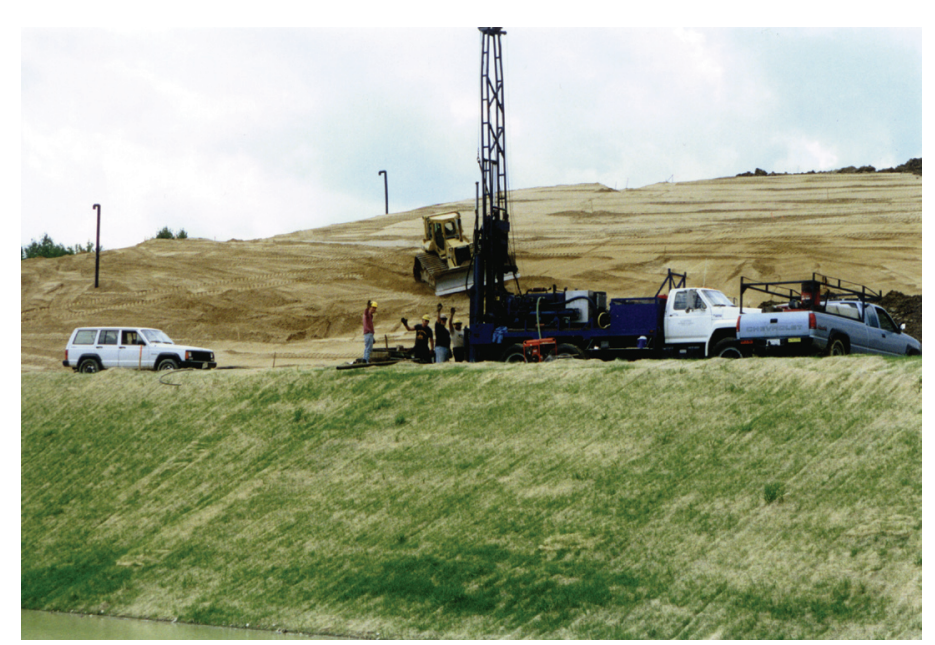

Photo 1. Drill rig installing monitor well at Saco Area 4 Landfill (landfill forms hill in background).

bedrock aquifer (fig. 2). The average arsenic concentration in the leachate plume is $326 \mu \mathrm{g} / \mathrm{L}$ (range $52-647 \mu \mathrm{g} / \mathrm{L}$ ). Essentially all of the arsenic is arsenite [As(III)].

\section{ARSENIC SOURCE IN GROUND WATER}

United States Geological Survey studies on the geochemistry and mineralogy of the leachate-contaminated aquifer at the Saco Area 4 landfill have shown that the source of arsenic is not the landfill but the sediments the leachate is moving through (Stollenwerk and Colman, 2003). Much of the arsenic is pres-

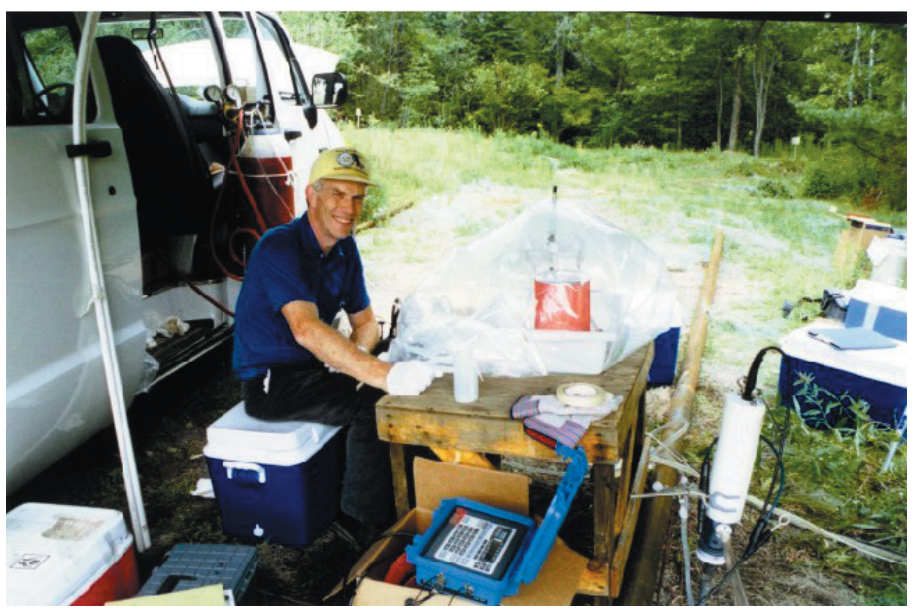

Photo 2. Collection of ground-water samples. 


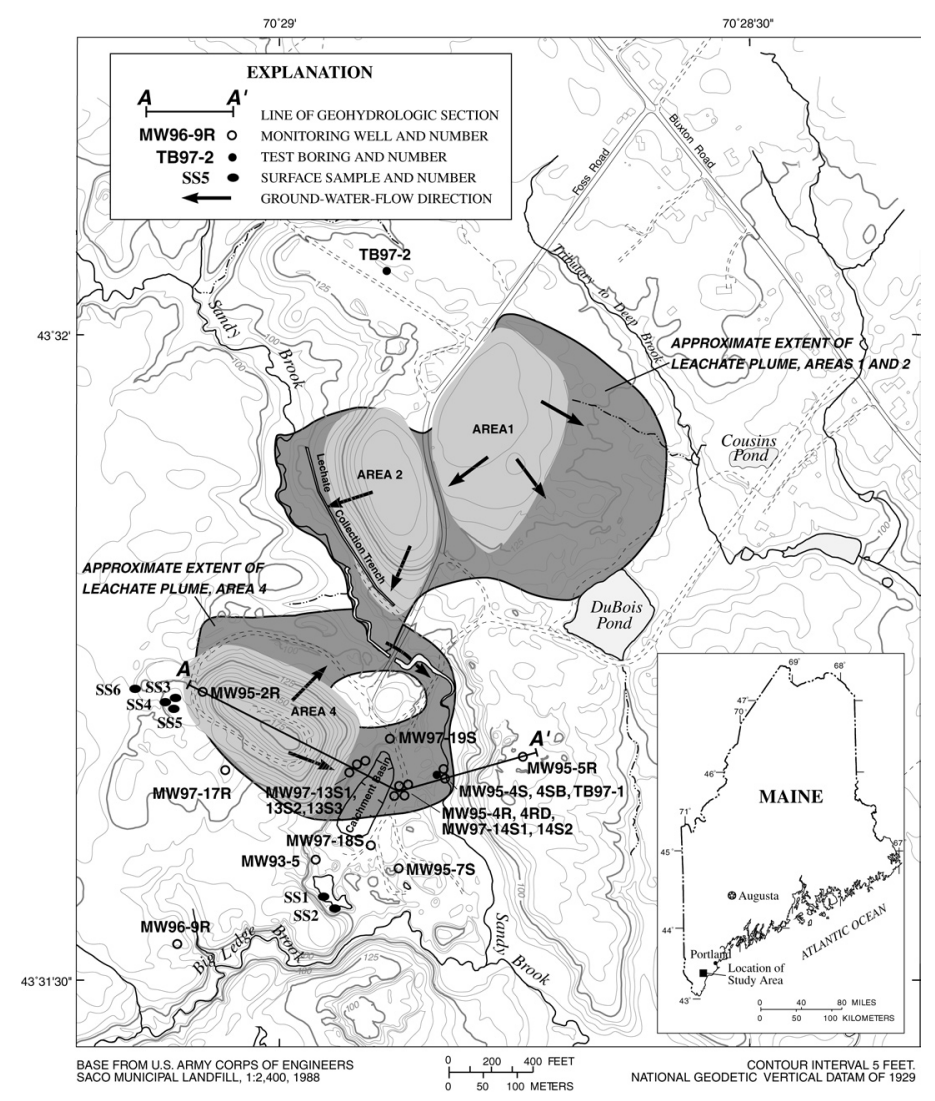

Figure 1. Site map for the Saco Landfill.

ent in hydrous ferric oxides that coat the aquifer sediments. The arsenic in these hydrous ferric oxides may have gradually accumulated over time as a result of adsorption of low concentrations of arsenic that occur naturally in the ground water of this area. Results from laboratory experiments show that dissolved organic carbon in the leachate plume is promoting

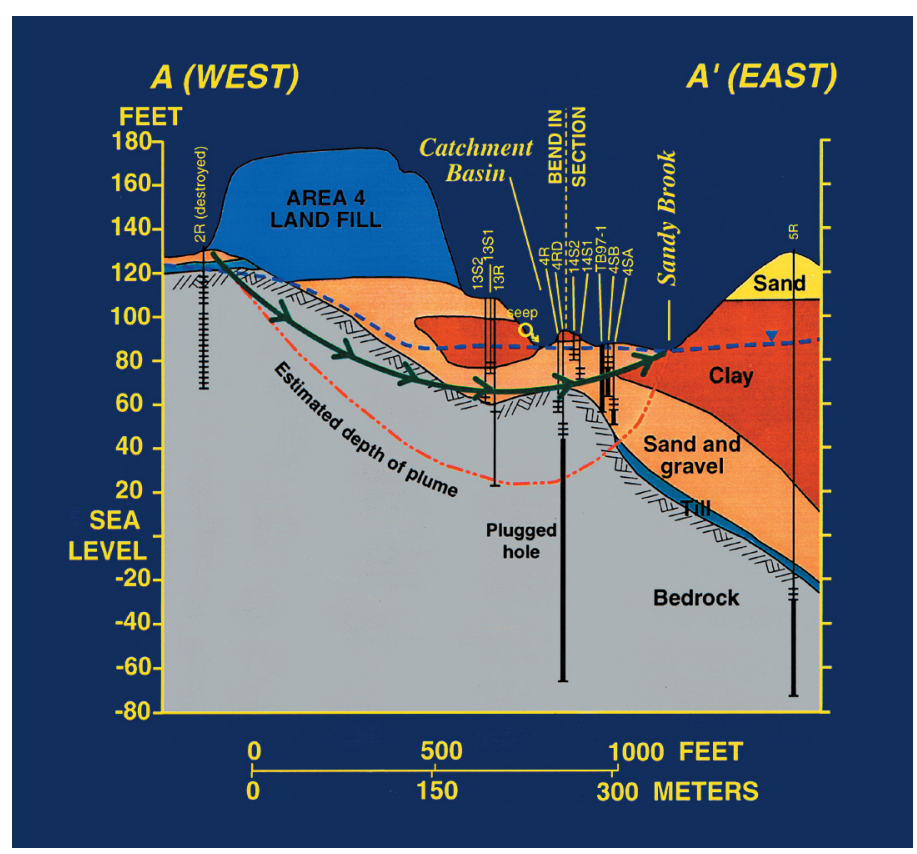

Figure 2. Geohydrologic section line A-A' for Area 4. Green arrows indicate modeled flow path of arsenic concentrations (from Stollenwerk, 2001). reductive dissolution of these hydrous ferric oxides, releasing arsenic to ground water. Reductive dissolution occurs because the degradation of the dissolved organic carbon in the plume removes oxygen from the water and creates reducing conditions that favor the dissolution of hydrous ferric oxides and release of arsenic from the sediments. As a result, there is a correlation between increasing concentrations of dissolved iron and arsenic in the Area 4 leachate plume (fig. 3).

\section{NATURAL REMEDIATION OF ARSENIC}

\section{Approach}

The impermeable landfill cover was installed to reduce infiltration of anaerobic leachate from the landfill and allow natural flushing of the aquifer with oxygenated ground water upgradient from the landfill. To assess the effectiveness of this natural remediation strategy, laboratory experiments and modeling studies were conducted to predict arsenic concentrations in

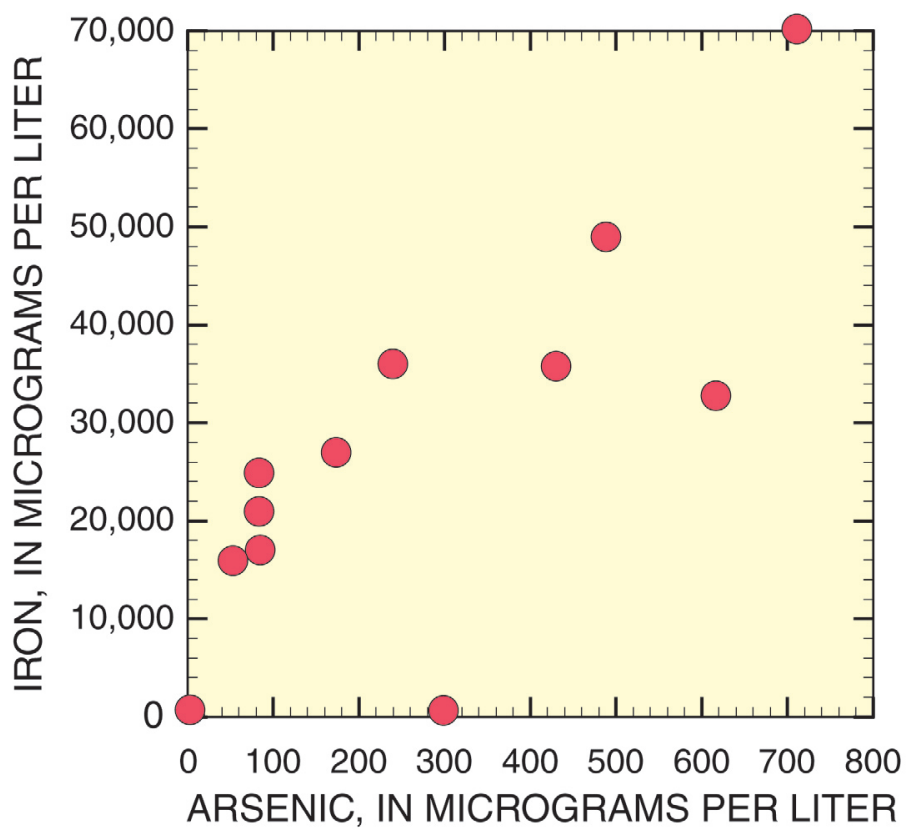

Figure 3. Concentrations of dissolved iron and arsenic measured in ground water contaminated by Area 4 landfill leachate.

the aquifer for as many as 50 years after the landfill was covered (Stollenwerk and Coleman, 2003).

The laboratory experiments consisted of flushing oxygenated, arsenic-free, uncontaminated ground water from the site through cores collected from leachate-contaminated areas in the aquifer. An average velocity of $0.2 \mathrm{~m} / \mathrm{d}$ (meters per day) was used for these experiments and is consistent with average ground-water velocities in the aquifer. Water eluting from the contaminated core was analyzed for arsenic and other selected constituents. The data from these experiments were used to: 1) measure the volume of uncontaminated water required to decrease arsenic concentrations to the $10 \mu \mathrm{g} / \mathrm{L}$ drinking water standard, 2) identify those reactions that had a significant effect 
on arsenic concentrations in ground water, 3) determine equilibrium constants for these reactions at this site, and 4) use the laboratory experimental data to simulate arsenic concentrations in leachate-contaminated ground water after the landfill was capped.

The one-dimensional reaction-transport model PHREEQC version 2 (Parkhurst and Appelo, 1999) was used to simulate chemical changes resulting from elution of uncontaminated ground water through the leachate-contaminated cores. PHREEQC has the capability to model advective transport of water in combination with a variety of chemical reactions. After calibration of the model to match the data from the laboratory experiments, the model was used to simulate geochemical changes resulting from 50 years of flow of uncontaminated ground water through the contaminated aquifer.

\section{Laboratory Results}

The most important reactions in this system are driven by organic carbon. In addition to the dissolved organic carbon present in contaminated ground water, significant concentrations of organic carbon also have been adsorbed onto the aquifer sediments during the active lifetime of the landfill. In the laboratory experiments, as uncontaminated ground water moved through the contaminated cores, organic carbon was continually released from the solid phase to solution, consuming all dissolved oxygen. As a result, reducing conditions within the core were maintained and hydrous ferric oxides continued to dissolve.

Iron concentrations in leachate from a representative core are shown in figure 4 . Iron concentrations rapidly decreased from $50 \mathrm{mg} / \mathrm{L}$ (milligrams per liter) to $5 \mathrm{mg} / \mathrm{L}$ within a few pore volumes as iron-free uncontaminated ground water displaced the contaminated pore water. (One pore volume is equal to the volume of water within the pore space of the core.) Iron concentrations then stabilized at about $3 \mathrm{mg} / \mathrm{L}$, indicating equilibrium between dissolved organic carbon and hydrous ferric oxide dissolution. By pore volume 250, organic carbon concentrations had decreased to a level where there was sufficient dissolved oxygen present in the core to prevent any further reduction of hydrous ferric oxides.

Arsenic concentrations from the same core decreased in a manner similar to iron (fig. 5). Arsenic concentrations rapidly decreased from $380 \mu \mathrm{g} / \mathrm{L}$ in the initial pore water to $50 \mu \mathrm{g} / \mathrm{L}$ by pore volume 15 . This fraction represents arsenic in pore water and the readily desorbable fraction. Dissolution of hydrous ferric oxides and release of associated arsenic to solution maintained arsenic concentrations at greater than $10 \mu \mathrm{g} / \mathrm{L}$ until conditions in the core became oxic (after organic carbon concentration had decreased), at about pore volume 250 .

\section{Model Simulations}

The concentrations of arsenic in the aquifer simulated by the model are shown in figure 6. Initial arsenic concentrations in 1998 (0 years after capping the landfill) are shown along a flow path that extends from beneath the landfill (zero meters) to Sandy Brook (300 meters). The simulated flow path encompasses areas underlying the landfill with the highest concentrations of arsenic measured in the ground water. The model

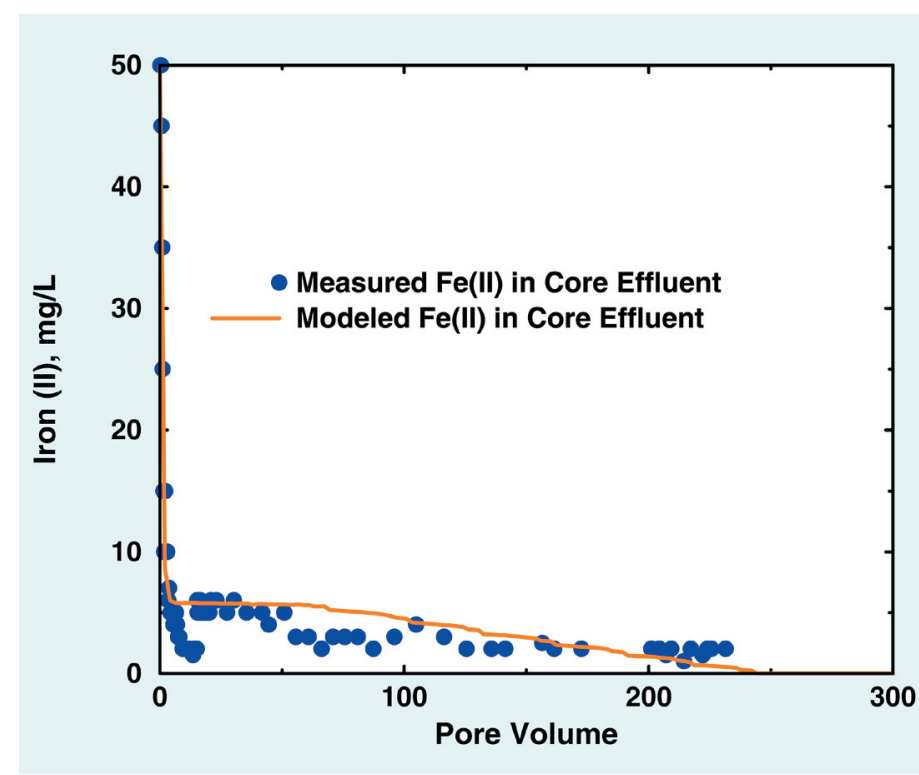

Figure 4. Experimental and modeled ferrous iron [Fe(II)] concentrations in leachate from one core (from Stollenwerk and Coleman, 2003).

assumptions are: 1) there is no further contamination of the aquifer by leachate from the landfill after 1998, 2) oxygen-containing uncontaminated ground water begins moving through the contaminated aquifer in 1998, and 3) ground-water flow is one-dimensional with no solute diffusion.

Modeling results show that arsenic concentrations at Sandy Brook could increase in the near term as higher concentrations closer to the landfill migrate through the aquifer. However, concentrations throughout the aquifer should gradually

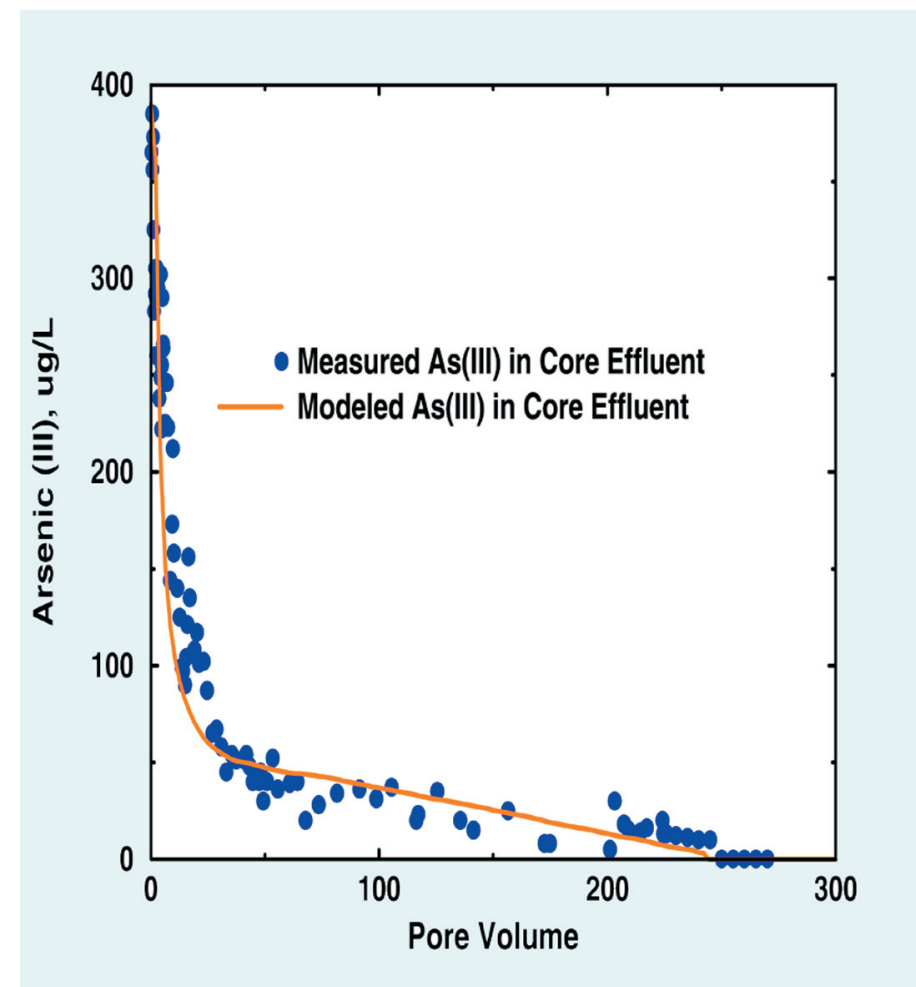

Figure 5. Experimental and modeled arsenite [As(III)] concentrations in leachate from one core (from Stollenwerk and Coleman, 2003). 


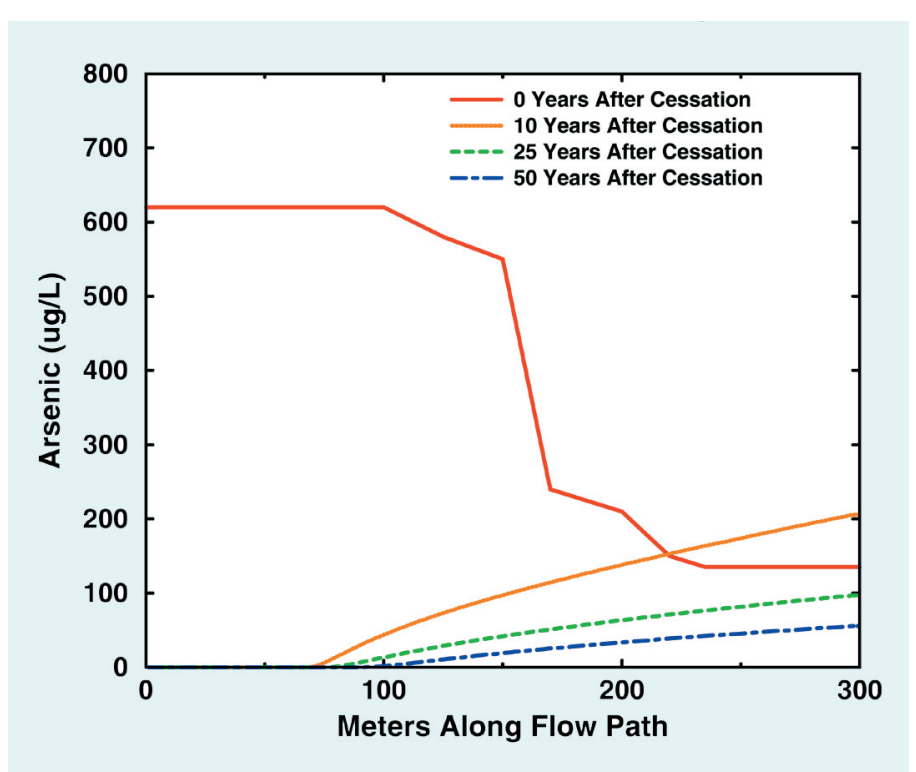

Figure 6. Model simulated concentrations of arsenic along flow path as a function of time after capping of the landfill. (Zero meters along flow path represents contaminated ground water beneath upgradient area of landfill; 300 meters is discharge at Sandy Brook) (from Stollenwerk, 2001).

decrease as uncontaminated ground water moves through the aquifer. Because of the large concentrations of organic carbon in this aquifer, decades may be required for arsenic concentrations to decrease to drinking water levels.

\section{IMPLICATIONS}

These results indicate that arsenic contamination of ground water could be a problem in other areas of New England that have been affected by landfill leachate, provided a source of arsenic is present in the bedrock and alluvial materials. Arsenic contamination of ground water may persist for many years after closure of a landfill because of the high organic carbon content of contaminated sediments, which maintain reducing conditions favorable for reductive dissolution of arsenic-containing iron oxides. This study also provides information on the geochemical processes that might cause high arsenic concentrations in ground water in other locations not associated with landfills. Two key factors are the initial presence of arsenic in the geologic materials of an aquifer and a reducing geochemical environment.

\section{—Kenneth G. Stollenwerk and John A. Colman}

For more information, contact:

Chief, Branch of Regional Research

U.S. Geological Survey

Denver Federal Center, Box 25046, MS 418

Denver, CO 80225

\section{REFERENCES}

Ayotte, J.D., Nielsen, M.G., Robinson, G.R., Jr., and Moore, R.B., 1999, Relation of arsenic, iron, and manganese in ground water to aquifer type, bedrock lithogeochemistry, and land use in the New England coastal basin: U.S. Geological Survey Water-Resources Investigations Report 99-4162, 60 p.

Ayotte, J.D., Montgomery, D.L., Flanagan, S.M., and Robinson, K.W., 2003, Arsenic in groundwater in eastern New England-Occurrence controls, and human health implications: Environmental Science and Technology, v. 37, p. 2075-2083.

Baedecker, M.J., and Back, William, 1979, Hydrogeological processes and chemical reactions at a landfill: Ground Water, v. 17 , p. $429-437$.

Christensen, T.H., Kjeldsen, P., Bjerg, P.L., Jensen, D.L., Christensen, J.B., Baun, A., Albrechtsen, H.J., and Heron, G., 2001, Biogeochemistry of landfill leachate plumes: Applied Geochemistry, v. 16, p. 659-718.

Marvinney, R.G., Loiselle, M.C., Hopeck, J.T., Braley, David, and Krueger, J.A., 1994, Arsenic in Maine ground water-An example from Buxton, Maine, in Proceedings of The 1994 Focus Conference on Eastern Regional Ground Water Issues, Burlington, Vt., Oct. 3-5: National Ground Water Association, p. 701-715.

Nielsen, M.G., Stone, J.R., Hansen, B.P., and Nielsen, J.P., 1995, Geohydrology, water quality, and conceptual model of the hydrologic system, Saco landfill area, Saco, Maine: U.S. Geological Survey Water-Resources Investigations Report, 95-4027, $94 \mathrm{p}$.

Parkhurst, D.L., and Appelo, C.A.J., 1999, User's guide to PHREEQC (version 2): U.S. Geological Survey WaterResources Investigations Report 99-4259, 312 p.

Peters, S.C., Blum, J.D., Klaue, B., and Karagas, M.R., 1999, Arsenic occurrence in New Hampshire drinking water: Environmental Science and Technology, v. 33, p. 1328-1333.

Stollenwerk, K.G., 2001, Natural remediation of arsenic-contaminated groundwater, in Eleventh Annual V.M. Goldschmidt Conference, Hot Springs, Va., May 20-24, Abstract, LPI Contribution No. 1088: Houston, Lunar and Planetary Institute, CD-ROM.

Stollenwerk, K.G., and Colman, J.A., 2003, Natural remediation potential of arsenic-contaminated ground water, in Welch, A.H., and Stollenwerk, K.G., eds., Arsenic in ground water-Geochemistry and occurrence: p. 351-379, Boston, Kluwer.

U.S. Environmental Protection Agency, 2001, National primary drinking water regulations-Arsenic and clarifications to compliance and new source contaminants monitoring: Federal Register, v. 66, no. 14, p. 6976-7066.

Woodard and Curran, 1998, Final remedial investigation report of Saco Municipal Landfill Superfund Site, Saco, Maine: Portland, Maine, Woodard and Curran, Inc., 180 p.

Zuena, A.J., and Keane, N.W., 1985, Arsenic contamination in private potable well, in U.S. EPA National Conference on Environmental Engineering, Northeastern University, Boson, Massachusetts, 1985, p. 717-725. 